\title{
Analysing joint work between activity systems
}

Analyser le travail conjoint entre différents systèmes d'activité

Analizando el trabajo conjunto entre sistemas de actividades

\section{Christine Owen}

\section{(2) OpenEdition}

\section{Journals}

Electronic version

URL: http://journals.openedition.org/activites/2040

DOI: 10.4000 /activites.2040

ISSN: $1765-2723$

\section{Publisher}

ARPACT - Association Recherches et Pratiques sur les ACTivités

\section{Electronic reference}

Christine Owen, «Analysing joint work between activity systems », Activités [Online], 5-2 I octobre 2008, Online since 15 October 2008, connection on 01 May 2019. URL : http://

journals.openedition.org/activites/2040 ; DOI : 10.4000/activites.2040

\section{(c) (i) (9)}

Activités est mis à disposition selon les termes de la licence Creative Commons Attribution - Pas d'Utilisation Commerciale - Pas de Modification 4.0 International. 


\title{
Analysing joint work between activity systems
}

\section{Christine Owen}

\author{
University of Tasmania \\ Christine.Owen@utas.edu.au
}

\begin{abstract}
This paper aims to contribute to the development of third-generation activity theorizing. It does so by analysing (inter)acting subjects engaged in joint work at the borders of their respective activity systems. The paper explores these issues theoretically by discussing practices observed in pilot-controller interaction in the aviation industry. In this case the way in which work practices are jointly mediated through changes occurring in interacting activity systems are examined. The analysis will show how the changes in elements of the activity systems reveal points of tension and contestation and thus opportunities for development in the everyday interactions between air traffic controllers and airline pilots. In undertaking the analysis, the paper introduces some key questions for consideration when designing interventions in such work environments and contributes to the development of third-generation activity theory.
\end{abstract}

KEY WORDS:

Cultural-historical activity theory, air traffic control/aircrew coordination, collaboration, organisational theory.

\section{Introduction}

In an article in this journal, Virkkunen (2006), discusses the dilemmas of facilitating organisational change in order to create improved working practices. In that paper, he noted that transforming activity often involves forms of collaboration that cross established organisational boundaries. He then discussed how change agents encounter dilemmas that inhibit proposed changes from being both identified and sustained. I share Virkkunen's goal of improving working practices and concern about visibilising work practices. In this case my interest is about how acting subjects engage in interaction on the borders of their activity systems and what enables or constrains their collaboration.

The analysis here assists in developing a framework that can be used by researchers and practitioners to analyse what enables and constrains cross-organisational collaboration by revealing tensions occurring at the borders of interdependent activity systems (Engeström, Engeström, \& Karkkainen 1995).

\section{Joint work between interdependent activity systems}

It is well known that for many people work has been increasing in its intensification, complexity and interdependence. In part, this has come about because of the growth of the knowledge economy and globalisation, changes in working arrangements resulting in flatter organisational structures and the increased capacity of information and communication technologies to add layers of interconnectivity which increases demands for responsiveness both within and between organisations (Casey, 1999; Gerber, \& Lanksherar, 2000; Rouilleault, 2000; Boreham, 2002; Engeström, 2005). With these changes comes increases in failures and the possibilities for failure, so metimes with significant consequences (Weick, 2006; Woods, 2006). The challenges of the changes leads to workers increasingly 
operating in environments characterised by:

- dynamic and continually changing conditions;

- task interdependencies involving multiple agents;

- work intensification leading to the need for greater responsiveness and working within shorter time frames; and

- work abstraction through information service provision involving interpretation of symbols and demands for higher-order thinking.

A good example of the above conditions can be found in the aviation industry, specifically in the joint work undertaken between pilots flying aircraft and ground controllers managing air traffic flow. In the aviation industry the challenges have been driven by increased demands for air travel which has led to more flights and increased pressure on airspace density. This in turn has led to calls for closer air-space separation between aircraft. Escalating costs of fuel and maintenance puts pressure on both pilots and controllers to provide an efficient service. In addition, concerns about air safety are paramount to operators. In order to address these demands, technological developments have enabled increased inter-operability, creating closer interdependency between air crew and controllers. These developments provide considerable cognitive and communicative challenges for the operators involved.

In this paper I want to argue that it is important to better understand what enables and constrains the accomplishment of joint work, particularly in domains such as aviation.

The aim of this paper then is twofold. Firstly, to offer new insights into air crew/traffic control collaboration by reframing such action as joint work occurring at the borders of two interacting activity systems. Secondly, to contribute to the development of what Engeström (2006) calls third-generation activity theorising. According to Engeström (2000b; 2004), the third generation of activity theory is one where emphasis is given to multiple perspectives distributed across networks of intersecting activity systems. Engeström uses three main concepts to advance this idea: boundary crossing (Engeström, et al., 1995); knotworking (Ahonen, Engeström, \& Virkkunen 2000) and co-configuration (Engeström, 2000a, 2004). In this paper I will contribute to this development by employing concepts from organisational theory to aid in understanding joint work practices at the border of interacting activity systems and in so doing, hope to also make a contribution to third generation activity theorizing.

To begin, it is first necessary to place the developmental trajectory of joint air traffic control/air crew work in context through a brief review of related research.

\section{Interdependency in air-crew/ground control work}

Inherent in air-crew/traffic control work is interdependence. The work of the pilot cannot be successfully accomplished without the air traffic controller, at least not in its present form. Without the pilot, the work of air traffic controller would not exist. However, the joint accomplishment of this work faces many challenges.

The first is that the work between pilots and air traffic controllers occurs in a virtual space. This is because, although working conjointly and interdependently, they are never co-present. The physical work space for the pilot is the flight deck of the aircraft and the work space for the air traffic controller is the ground control centre. Most of the communication work undertaken by acting subjects between these two work spaces occurs via radio as well as, in advanced aircraft operating in a certain flight phases, through e-mail like text (known as controller-pilot data link communication). Nevertheless, they are each engaged in the joint accomplishment of the work. They share a mutual enterprise and they hold each other mutually accountable for particular aspects of that work. They share language, routines and artefacts. Moreover, to achieve successful flight they have to trust each 
other. Pilots are literally putting their lives and the lives of their passengers in the hands of the unseen voices of air traffic control. Controllers are trusting pilots to act in accordance with their instructions as they manage multiple aircraft, each containing often hundreds of people, through a particular finite block of airspace.

For over 25 years, researchers have explored human factors and approaches in an attempt to understand what contributes to error and to enhancing safety in these environments (Hollnagel, \& Woods, 2006). However, even in recent times, the overall focus within the aviation human factors literature has remained largely on either the technological systems level (Field, \& Harris, 1998; McGann, Morrow, Rodvold, \& Mackintosh, 1998; Dekker, 2000; Prinzo, 2004; Rantanen, McCarley, \& Xu, 2004) or on the cognitive or communicative resources level (Cushing, 1995; Fowler, 1999; Salas, Bowers, \& Edens, 2001; Yule, Flin, \& Murdy, 2007).

As technologies and systems have become more interconnected, attention has shifted to developing inter-operable systems and to investigating the implications of those systems for the respective -positional roles of the actors (McCann, Baranski, Thompson, \& Pigeau, 2000; Smith-Jentsch, Baker, Salas, \& Cannon-Bowers, 2001). In fact, in the 1990s, the integration of the aircrew/ground control systems was regarded, in the aviation human factors literature, as the biggest challenge of the 21st century. However, integrating technologies to support aircrew/ATC work activity was no easy task. Kerns (1999, p. 520), for example, noted that the technological systems supporting air crew/ground control work activity have historically been built "to interoperate within their respective systems not between them" (emphasis added). This, according to Kerns (ibid.), was because "the design of ground-side and air-side systems has been driven by internal organizational objectives and technology, neither the procedures nor the tools are well adapted for coordinated use by controllers and pilots to achieve common goals". It should be noted that the problem of inter-operability between systems and their operators does not affect the aviation domain alone and this issue is likely to become more important with increasing interconnectivity in the future (Howitt, \& Leonard, 2006).

Research has also focussed on how and why communication breakdowns resulting in death can occur between apparently highly trained and technically proficient personnel (Loftus, 1979; Wiener, Kanki, \& Helmreich, 1993). An emphasis within the human factors literature, and one that continues to be important, has been on contributing to safety by enhancing the communicative resources available to aviation personnel through teamwork. Most of this research development has involved teams, including those in aircrews (Kanki, \& Palmer, 1993; Morrow, Rodvold, \& Lee, 1994; Orlady, \& Orlady, 1999; Salas et. al., 2001; Salas, Stagl, \& Burke, 2004) and in air traffic control (Hartel, \& Hartel, 1995; Smith-Jentsch et al., 2001). Within this literature base, attention has been paid to understanding why situation awareness between the parties may break down (Jentsch, Barnett, Bowers, \& Salas, 1999), what verbal and non-verbal strategies members may use to maintain a shared cognitive picture (Segal, 1994) and what strategies can be employed in training interventions to encourage members to create a team mental model (Salas et al,, 2001; Salas et al., 2004).

While the above research provides some insights it overlooks two important considerations. Firstly, it is difficult, on closer inspection, to characterise joint ATC/aircrew work as teamwork in the way teams are typically defined. Teamwork is typically defined (Baker, \& Salas, 1992, p. 469) as

a distinguishable set of two or more people who interact dynamically, interdependently and adaptively toward a common and valued goal/ objective/mission, who have each been assigned roles or functions to perform, and who have a limited lifespan of membership .

While air crew-ground control work meets these criteria, few controllers and pilots would believe they constituted a team, in part because the limited lifespan of membership is so tenuous. The usual indicators of teamwork effectiveness (e.g., cohesiveness) would not apply. Secondly, a focus on systems or on communicative processes alone does not provide a satisfactory account of what enables and constrains successful joint practice. This seems a considerable oversight. I wish to argue that what is needed is a more comprehensive account of the development of joint work activity by ex- 
ploring the tensions and contradictions inherent within the work by examining underlying processes and structures. This can be undertaken by reframing such work as representing interdependent activity systems-in-interaction. In order to elaborate on this idea is it first necessary to outline some key principles of Cultural Historical Activity Theory (CHAT) and the development of third-generation activity theorising.

\section{Three generations of cultural-historical activity theory}

In activity theory, three generations of research development have been identified by Engeström (2000a, 2000b; 2005). The first generation of activity theory, according to Engeström, centres on Vygotsky's concept of mediation. The significance of this concept was that it overcame the Cartesian individual-society split by demonstrating how cultural artefacts mediated human actions. This development provided a profound shift in thinking about activity, and considerable research since has employed this concept of mediated activity. That said, the research was limited in that the focus remained largely at the level of the individual.

The second generation of activity theory research centred on the work of Leont'ev (cited in Engeström 1999; 2000a), who emphasised the collective nature of activity. This approach enabled analysis of the complex interrelations between individuals and their communities and, in particular, the ways in which collective goals were achieved, for example, through divisions of labour. It added a new dimension to theorising and represented a considerable leap forward as it accounted for individual as well as collective action. In large part, because of Engeström's success in introducing the West to these ideas from Russian psychology, activity theory has attracted an increasingly international (and diverse) audience.

According to Engeström (2000a; 2005), the third generation of activity theory involves investigating collective, artefact-mediated and object-oriented activity in its network relations to other activity systems. In this approach particular attention needs to be paid to diversity or multi-voicedness between different traditions and perspectives that have historically developed within respective activity systems. The emphasis within third-generation CHAT development is on developing conceptual tools to understand "multiple perspectives and networks of interacting activity systems" (Engeström, 2005, p. 62). This is important given the increasing interdependencies of a variety of work contexts, such as that found in joint operations between air crew and ground control. However, as Engeström (2005, p. 93) argues, where actors are temporally and spatially distributed, the actions taken are influenced by far more than simply the communications observably present in any given situation.

Engestrom employs three concepts to develop third generation activity theory. Boundary crossing (Engeström 2001), knotworking (Ahonen, Engeström, \& Virkkunen, 2000) and co-configuration (Engeström, 2000a, 2004).

Engestrom noted that boundary crossing is a broad and little studied category of cognitive and organisational processes. He and researchers at the Center for Activity Theory and Developmental Work Research, have studied boundary crossing as a process of collective concept formation and expansive learning (Engeström 2001; Engeström, Engeström, \& Kerosuo, 2003).

To date there are at least two approaches taken to conceptualise boundary crossing within the Cultural Historical Activity Theory literature. The first focus refers to boundary crossing as an ephemeral, and temporary phenomena known as "knotworking": The notion of a knot refers to a rapidly pulsating, distributed and partially improvised orchestration of collaborative performance...characterized by a "pulsating movement of tying, untying and retying otherwise separate threads of activity .... The locus of initiative changes from moment to moment in a knotworking sequence" (Engeström, Engeström, \& Vähääho, 1999, p. 346).

Engestrom and colleagues give the example of the successful collaboration that occurs between an apartment building janitor, a concerned neighbour and two paramedics in trying to make contact 
with a mentally-ill woman. In this conceptualisation, boundaries are crossed, though in a fleeting and transient way in order to solve a temporary problem. For Engestrom and colleagues the key to understanding these new ways of working is to acknowledge that there is no centre of coordination. Instead, the locus of initiative moves between actors and their roles. This is in contrast with a second conceptualisation, of boundary crossing associated with expansive learning and developmental work research which, it can be argued is more durable, since it leads to the development of new tools. In this conceptualisation, intervention work leads to the development of new tools to create new forms of innovative working. An example of this is found in Engestrom and colleagues' use of the Change Laboratory as a means of developmental intervention.

The idea of boundary-crossing and knotworking seem to have provided the platform for the development of the concept of co-configuration. Drawing on the idea initially developed by Victor and Boynton (1998), co-configuration is, for Engestrom and colleagues, an emerging new type of work that involves a collaborative partnership between multiple producers or networks of suppliers who form strategic alliances with customers where a complex package of services or products is developed (Engestrom 2000a; 2004). This is more than just responding to customer needs because coconfiguration takes the company-customer relationship to a new level by developing an interactive collaboration where "the customer becomes, in a sense, a real partner with the producer" (Victor, \& Boynton, 1998, p. 199 in Engeström, 2000, p 973). Co-configuration requires flexible "knotworking", which is seen as the emerging interactional core of co-configuration, within which still "the centre does not hold" (Engeström, 2000).

In third-generation activity theorizing, the challenge then, is to develop an understanding of "how forward-oriented expansive learning actions are intertwined with horizontal or sideways movement across competing or complementary domains and activity domains, particularly characteristic to coconfiguration" (Engeström, 2004).

In this paper, I wish to take up this challenge and to demonstrate how, while joint work practices may comprise many of the features characterised as "knotworking" and thus be regarded as temporary and ephemeral, there are necessarily occurring within still distinct centres of coordination in activity systems which can and in fact still do "hold". In demonstrating the way in which joint practice is negotiated at the borders of interacting activity systems I will also show, through employing concepts from organisational theory, how those practices move forward through sideways or horizontal movement in order to resolve tensions found when the joint work practices of interacting activity systems reveal competing objects. Resolving these tensions in turn are layered into, not ephemeral and transitory but more durable working practices and interacting activity systems develop over time.

Before discussing how air crew/ATC work can be analyzed in this way it is important to say something about the research base from which the ideas discussed here have emerged.

This paper is not an empirical one. Instead it develops a theoretical framework extrapolating from previous research in order to draw out the implications for this conceptualisation. Nevertheless, an outline of the data collected that led to this formulation might be helpful in order to provide context.

\section{Previous research conducted into ATC/aircrew activity systems}

The data that was drawn on in order to develop this analysis was collected through two complementary research studies. In the first study, an interpretive qualitative design was used where a stratified sample of 100 air traffic controllers were interviewed, often on multiple occasions over a three year period. Controllers were interviewed at three ATC Centres in Australia at a time when considerable organisational change was occurring. The focus of that study was on analysing the ways in which organisational structures and cultures enabled and constrained learning in the workplace. The methodological details of this study and its broader conclusions have been reported elsewhere (Owen, $1999 ; 2001)$. The second and consequent research study was undertaken over a three-year period 
and examined the impact of changing technologies on air traffic controller/aircrew communication and collaboration. During this study, 60 hours of close observational work of pilot-controller and controller-controller interaction was undertaken over low, medium and high workload periods and across differing ATC sectors and with differing aircraft types. During this phase, 83 interviews were conducted, the majority post-observation (63 interviews with air traffic controllers and 20 with pilots). Over this entire data collection period the author also operated as a facilitator of professional development courses and other organisational change initiatives within the Australian civil air traffic control organisation.

\section{Conceptualizing air crew/controller work as interacting activity systems}

While pilots may be able to manage flight by themselves, they currently cannot do so in a coordinated way with other traffic. Likewise, there would be no work for a ground control system if not for the activity of airlines and aircrew. Yet despite their close dependency, the argument here is that they are not part of one activity system but rather represent the overlapping interests of two interacting activity systems. That is, it is the joint work of the two interdependent acting subjects that are in interaction, and the practice of joint work is the unit of analysis. In the following analysis of joint work, the elements of each activity system are evident, as are the relationships between them and the problems raised at the border of joint work as the developmental trajectory of work activity within activity systems creates tensions between them.

\section{Elements of interacting activity systems}

Engeström characterises an activity system as one that has a coherence between the object-oriented activity for the Acting Subjects in their use of their artefacts, organised collectively within their divisions of labour, rules employed and community (of interests, practice, or culture) (see Figure 1).

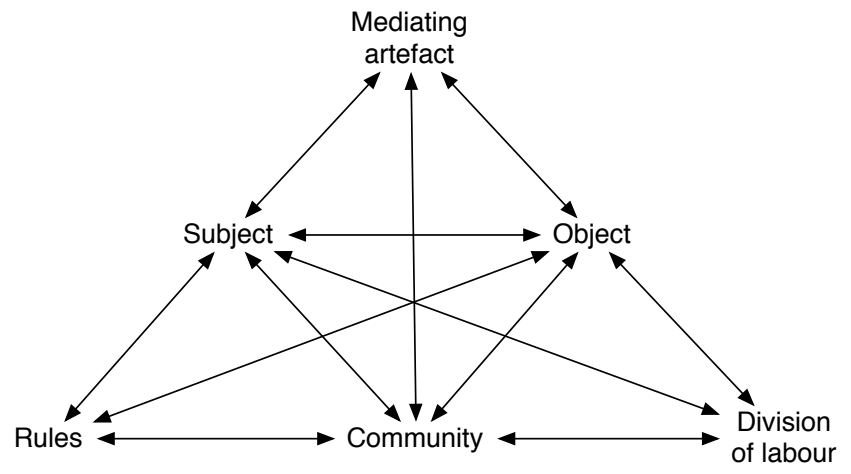

Figure 1: Components of an activity system

As will be illustrated below, the object-oriented activity undertaken by an airline represents one such activity system, where the acting subjects are the air crew, 


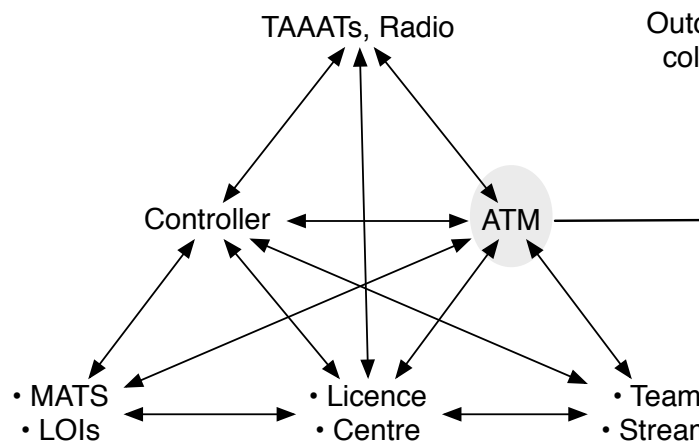

Outcome: Successful collaboration, flight

Figure 2: Components of interacting activity systems

complete with their artefacts, divisions of labour, rule and communities; and another is the air traffic control system, represented by the air traffic controller and their tools, rules, division of labour and community. Figure 2 illustrates the ways in which these two activity systems can be identified and their interconnection analysed. Within each activity system, acting subjects (e.g., controllers and pilots) aim to successfully achieve their object-oriented outcomes. Their actions are mediated by tools, rules, divisions of labour and communities of practice.

In Figure 2, one the left hand side, the air traffic controller (acting subject) uses tools such as the radio, radar and computer-generated flight technologies (such as those built into The Australian Advanced Air Traffic Control System (TAAATS) to manage air traffic in non-radar airspace) to achieve the object of the safe, orderly and expeditious flow of air traffic. The success or otherwise of these actions (outcome) is mediated by the use of that technology, together with other influencing factors such as the rules (e.g., Local Operating Instructions) governing a particular airspace. The cultures from a range of communities of practice with which the controller identifies can also be identified and these too influence the strategies the controller will employ in the course of undertaking the work. For example, these can include identification with and belonging to groups based on their affiliation with parts of the aviation community (e.g., general aviation, military), identification with the different kinds of airspace sectors the controller is licensed to control (e.g., approach/departure, arrivals, enroute, tower) and so on. Also influencing the work activity is the division of labour within which the acting subject may work. In air traffic control this includes, for example, being part of a team operating within a particular stream of traffic management (e.g., enroute, tower, arrivals or approach/departure). Depending on the complexity and number of airspace sectors within each stream, there may be three or more teams operating a group of sectors within a particular stream.

A similar activity system guides the work of the aircrew. The pilot flying the aircraft will have the object of achieving a safe, orderly and expeditious flight path for this particular aircraft. The pilot will be part of a team of two to four people who will use the aircraft's flight system, which in more technologically advanced (glass) cockpits will be a computer-generated Flight Management System. The crew's work activity will be governed by the formal division of labour (pilot-flying, pilot not-flying, with input as necessary from other support personnel, such as the flight engineer) and the rules (e.g., standard operating procedures governing that particular aircraft). The pilot, too, will be part of a variety of communities of practice that may include groups they identify with on the basis of their history of experience (e.g., where they did their training, whether they were military pilots prior to joining a civilian airline), what kind of aircraft they are licensed to fly (e.g., Boeing 777; Airbus A320) and what kind of organisation they fly with (e.g., international or a low-cost regional airline).

In the process of tracking through an airspace, an aircrew will communicate with controllers who are sometimes operating between three and eight different ATC sectors of airspace within the one Australian Air Traffic Control Centre. Moreover, some of these interactions between particular controllers and the aircrew will last only three to five minutes (e.g., in the case of an approach/departure sector) or could last up to two hours (for an enroute sector). Under these circumstances, the joint actions of the controllers and pilots occur only momentarily. 
In this situation, it is interesting to consider, firstly, the ways in which the object is constituted by the respective acting subjects as they operate across these activity systems and, secondly, how this enactment creates (and is in turn influenced by) tensions and contradictions in various components of the activity system in the achievement of that object. In the example in Figure 2, these two activity systems overlap to the degree that they share a common object (joint management of the flight). However, the shared object is not always directly aligned and is only ever overlapping. For example, whereas the object of the air traffic controller's actions is the safe, orderly and expeditious management of the flow of air traffic through an airspace; the object of the aircrew's actions is the safe and expeditious flight of their particular aircraft. The objects of the respective activity systems overlap when both acting subjects are involved in the joint accomplishment of the management of the flight.

However, sometimes the joint accomplishment of this mutually constituted object is in tension based on influences from the demands within each of the respective activity systems. For example, in the course of the flight, the pilot is likely to want to ensure fuel efficiency is optimised (some air carriers give pilots a bonus at the end of the month if fuel has been saved). The pilot will also have an interest in ensuring the aircraft flies at its optimum performance profile and that passengers are not inconvenienced through delays or turbulence (to do otherwise would not be professional). On the other hand, the primary interest of air traffic controllers is managing competing demands placed on them to optimise traffic flow through a particular airspace. This means, for example, that when an air traffic controller managing the flow of air traffic directs a pilot in a way that is at odds with the pilot's desired object (e.g., putting the aircraft into a landing sequence that will delay the aircraft's planned arrival), there is likely to be tension that sometimes results in contestation on the part of the pilot $^{1}$. Such strategies have been reported by Besco (2000), for example, when pilots sometimes bend the truth in terms of their location and arrival time estimates so that they may secure a higher place in the landing queue.

These theoretical developments offer strong possibilities for the exploration of the new terrain of joint work at the borders of activity systems. Engeström (2005) has put forward what he has termed a tentative concept, which he has called "object-oriented interagency". However, there is much to flesh out in order to provide a full picture of work practice as it occurs at the intersection of interacting activity systems. This paper aims to contribute to this development.

The problem still remains that the focus of analysis remains very much within activity systems with limited attention given to work negotiated between one organisation or domain of work and another despite the increasing number of interconnections between work activity and systems. Engeström (2000a) identified this weakness when he noted that, despite emergent organisational work contexts and forms, boundary crossing was a broad and little studied category of cognitive processes.

\section{Understanding work practices at the border of diverse activity systems}

How might this analysis assist in understanding the joint work of controllers and aircrew and what enables or constrains successful collaborative accomplishment? In the case example outlined above, two activity systems can be identified that are "bounded" by their respective use of tools, rules, divisions of labour and objects. The work of the respective acting subjects within these activity systems relies, however, on interactions with the other. The means by which this work occurs is through a common "boundary object" or interface (Nardi, 1996), such as communication through the technologies employed. However, as will be discussed below, there are also borders between the activity systems that characterise their demarcation. These borders may or may not be supported by suitable interfaces connecting them.

1. It should be noted this does not imply that a pilot would wilfully violate such direction, just that there may be some discussion or contestation. 
In this paper I will discuss the borders as they occur between acting subjects mediating their joint work through:

- the intersection of their respective artefacts or technologies - borders of inter-operability;

- their applications of their rules - borders of accountability;

- the interactions of their respective division of labour - borders of role responsibility;

- the similarities and differences in their professional cultural communities (borders of social identity).

There are no doubt other borders that can be identified. Since the above represents the main attributes emphasised in activity theory systems, they are used as the starting point for this discussion.

The summary of the two activity systems has highlighted how both systems can be represented in joint practice and how intersecting objects of the acting subjects may overlap while not being exactly the same. This paper will now consider what negotiating the borders of these activity systems reveals about the development of joint practice.

\section{Borders of inter-operability}

In activity theory, tools are artefacts that mediate between the subject and object of activity (see Figure 1). Engeström (2005) highlights the way in which tools can be both cognitive (i.e., mental models an acting subject may utilise; see for example Engeström, Engeström, \& Kärkkäinen, 1995) for a discussion) as well as technological. For an analysis of intersecting activity systems, it is useful to examine the ways in which the technological systems interconnect and the implications for cognitive tools employed by the various acting-subjects. As discussed earlier, it has been reported (Kerns, 1999) that technologies used in flight have been developed within each aircrew/ground control activity system and, as a consequence, are not well adapted for coordinated use across organisations to achieve common goals. For example, an air traffic controller works with a two-dimensional plan view of traffic that is well suited to radar separation procedures and representation of vector solutions to separation and spacing problems. In contrast, flight management systems used by airline pilots support vertical profile planning in all phases of flight to manage fuel and flight schedule requirements. Consequently, according to Kerns (1999), when a controller provides an instruction to a pilot to vector off track (as they frequently do), such an instruction imposes a higher cognitive load on the pilot attempting to execute and maintain a prescribed flight path than would appear based on the ATC representation using their technology.

In terms of the developmental trajectory of the work, currently the most commonly shared interface between ground/control and the flight deck is the radiotelephone. Up until recently almost all information and air traffic clearances have been transmitted over the radio. In aviation, the style of communication has been designed to ensure spoken communication can be conducted efficiently and expediently over channels often frequently used by operators. Yet the increase in traffic has resulted in an overloading of this medium. This has occurred because only one speaker can speak at a time and in busy environments this competition has resulted in messages being delayed or cut off. Moreover, in oceanic sectors sometimes VHF radio can be difficult to hear or to access. An innovative tool that has been developed is the Controller Pilot Data Link Communication device (CPDLC). CPDLC has a number of advantages and disadvantages that are beyond the scope of this paper (see Kerns, 1999). Some of the tensions emerging in the implementation of this new tool include the implications of the loss of party line information that pilots used to be able to access when listening on the radio (i.e., the dialogue between other pilots and relevant ATCs on the same frequency). A related technology that has been developed to provide situation awareness in the cockpit is Cockpit Display of Traffic Information (CDTI). This tool enables pilots in suitably equipped cockpits to detect, via a screen, other aircraft in their airspace. CDTI thus provides pilots with access to information similar to that available to the ground controller. The capabilities of these emergent, technological tools have 
led to pressure to change the division of labour between controllers and pilots in terms of their roles and responsibilities.

It is important to note that these new technological innovations are not replacing the older systems; they are supplementing them. This means that there is an increasing diversity of aircraft using different technologies resulting in a growing complexity in ATC because of the increasing number of border interfaces with which the controller has to contend.

Key questions for future research analysis and consideration in system interventions include:

- To what degree are the borders between artefacts technologically integrated and what are the implications for the cognitive load required to be employed by acting subjects?

- Are the numbers of borders that need to be negotiated increasing or decreasing and how many is a reasonable number for an acting subject to manage without decrements to the system?

It will be of no surprise to scholars of activity theory that all of these changes have implications for other aspects of the activity system.

\section{Borders of accountability}

In activity theory terms, rules refer to the "explicit and implicit regulations, norms and conventions that constrain actions and interactions within the activity system" (Engeström, 1999, p. 79). In highly formalised organisations, such as aviation, the discretion and autonomy of members is typically more limited than in less formalised organisations where there is more freedom to exercise choice. In this way, as Flach (1999) notes, rules are always about a trade-off between freedom and autonomy and regulation.

The term accountability is being used here in two ways. When people apply (or bend) rules, they "account" for their practices in certain ways (Suchman, 1993; 2000). Secondly, those in authority hold people "accountable" in terms of sanctions or support for such actions (McCarthy, Healey, Wright, \& Harrison, 1997). To analyse the ways in which acting subjects develop practices involving the negotiation of borders of intersecting rule systems, it is helpful to draw on some frameworks for considering the organisation of rules and to consider these issues of accountability (self as well as organisational). In discussing the application of rules in high-consequence organisations, McCarthy et. al., (1997) identify a set of dimensions that draws attention to the relationship between formal accountability and work activity in different contexts. These have been adapted here and include:

1.- Explicit-implicit - refers to the extent to which the application of the rules and procedures developed is presented in forms that are available either for external inspection (explicit) or not (implicit).

2.- Global-local - refers to the extent to which the rules and procedures are locally or globally structured. A rule is globally structured when people other than those involved in the work activity impose it. Whether a rule is globally structured also depends on the extent to which those involved are accountable.

3.- Stable-transient - refers to the extent of the flexibility involved in a situation. That is, the extent to which the application of rules and procedures is fixed or can change across situations.

4.- Dependent-independent - refers to the extent to which rules and procedures are separable from one another or are contingent on one another.

In complex work environments, rules and procedures can be assessed in terms of their location within each of these dimensions. Given the emphasis given in activity theory to the historical trajectories of work development, it is also useful to analyze the impacts on these dimensions as work systems change. In considering joint work at the intersection of activity systems, two issues are of interest. Firstly, given the historical trajectory of an activity system, how are these rule dimensions 
(and the application of rules and procedures) changing in relation to the achieving of shared objects? And, secondly, what are the implications for work at the border of connecting activity systems? For example, in Australian aviation, the advances that provide the development of new artefacts such as CPDLC are enabled, in part, because of their accuracy in pinpointing the exact spatial location of the aircraft in question (through their reliance on other tools such as satellites). These changes may make some rules that were previously largely implicit now explicit, and others that were stable under existing circumstances more likely to be transient in the future.

As an example, one of the key objectives of an airline is to have satisfied customers who feel they have received value for money from an airline that values their interests. In keeping with this desired object, pilots frequently (when they deem it to be safe to do so) take aircraft off their ATC-designated track to provide aerial views of tourist sites (e.g., a fly-past of Uluru when landing at Alice Springs). Tensions are now emerging because aircraft fitted with ETOPS tracking (satellite) capacity make such deviations now visible on the TAAATS console as having gone off track (whereas aircraft not fitted with that particular technology are not). Therefore, the bending of this rule will be transparent to the ATC activity system, if aircraft are fitted with certain technological tools, but opaque for other aircraft. Likewise, when an air traffic controller has the opportunity to share the object of assisting the pilot to achieve what they want in terms of flight path profiling, the ATC can when possible, assist by collaborating with the pilot to bend the rules by invoking a communication pattern that allows this to happen. For example, in response to a request from a pilot to descend, a controller might say "to facilitate descent I require that you are 60 miles due west of ...", to which a pilot will reply that the aircraft just so happens to have reached that location. Controllers are doing "what is needed" for successful flight, which includes providing a service that meets the pilot's desires to bend the rules.

There are, however, also tensions between pilots and controllers in regard to the application of rules of airspace separation in the management of air traffic. In response to the question "What would you like pilots to know about your work as an air traffic controller?" one respondent commented that he preferred to identify what he did not want pilots to know, which was the calculation of lateral separation standards on aircraft on converging flight paths. The controller did not want this information about the application of an air traffic control rule known within the pilot community because the controller believed that in order to get what they wanted, some pilots attempted to second guess the rule of airspace separation employed and provided information they thought the controller needed. Key questions for further consideration include:

- How are changes in the application of rules and procedures influenced by changing technologies?

- What is the nature (i.e., explicit/implicit, global/local, stable/transient, dependent/ interdependent) of the rules enacted in joint work between activity systems, how are these changing and what does this analysis reveal about how acting subjects develop practices of joint work?

- To what extent are the negotiations between acting subjects changing with the changes in the rest of the activity systems, such as technological development?

What this brief discussion highlights is the need in third-generation activity research to explore the nature of rules and their dimensions and the implications of changes in those dimensions for the borders between activity systems.

\section{Borders of role responsibility}

At the other end of the activity system framework is the division of labour, which will be discussed next because of its close links with rules. Division of labour refers to both the horizontal division of tasks and to the vertical division of power and status (Engeström, 2005). In organisational theory terms, these divisions of labour have to do with issues of complexity, centralisation and the exercise 
of power in organisations. In dealing with complexity, organisations use different strategies in terms of differentiation and integration (Jones, 1995) to divide labour and to coordinate it. Differentiation is the process by which people and resources are allocated to different roles, tasks and functions, as evidenced in the organisation's division of labour, while integration refers to the strategies used to coordinate those tasks, roles and functions (Jones, 1995). Engeström (2005) has distinguished between differentiation found in an organisational hierarchy (vertical differentiation) and that found in the way in which tasks and roles are organised into sub-units, functions or departments (horizontal differentiation).

Commentators on organisational design (e.g., Jones, 1995) contend that the challenge for organisations is to find ways of balancing differentiation with integration. For example, as a result of the technological innovations discussed earlier in this paper, there is tension developing over the division of roles and responsibilities between aircrew and controllers in terms of flight plan management. Certain sections of the airline industry are pushing for a re-evaluation of role responsibilities in terms of flight plan management. On the table for negotiation at a variety of international forums is the notion of "free flight", in which pilots change their own flight paths and separate their own aircraft in certain airspaces, provided they enter and leave such airspaces at certain virtual "gates". This division of role and responsibility would see a greater role given to the aircrew to manage their separation from other traffic.

Another potential division of labour between the two activity systems is the possibility of the air traffic controller setting up the sequence for landing and the aircrew managing the separation distance between their aircraft and others. This has led some in the industry (Kreifedlt, cited in Kerns, 1999) to conclude that pilots can maintain airspace separation standards better than controllers can.

Key questions of interest in this paper include:

- What are the implications of changes in artefacts for divisions of labour within activity systems in order to accomplish joint work between activity systems?

- What points of contestation emerge in how the division of labour is configured in joint work and what does this reveal for the conceptualisation of the shared object?

At issue here, in part, is the perceived status and power of the respective groups, which is, in turn, influenced by the social identity of the groups.

\section{Borders of social identity}

At the heart of the idea of "community" is the notion that individuals share what they know, formally and informally, as part of belonging to, and identifying with, a particular group. Engeström (1999) uses the word "community" to describe multiple individuals and/or subgroups that share the same general object. Blackler, Crump, and McDonald (1997) talk about "communities of activity" where expertise and learning is recognised as a collective phenomenon. In this paper, groups are described as having a sense of community when they share an identity within a common cognitive and technological infrastructure.

The focus on communities of activity (or, as some theorists prefer, communities of practice) is on interaction, both formal and informal, and the ways in which collective memory is built up over time. This focus also helps us understand the ways in which groups of interdependent individuals provide the context within which participants construct individual and social identities and the ways in which social context helps those identities to be shared (Brown, \& Duguid, 2001).

When individuals define themselves as part of a group, they justify their behaviour in terms of group norms and develop a group identity in terms of their interactions with others in the group and the responses of others to group behaviour (Fine, 1996). In terms of theories of social cognition (Augoustinos, \& Walker, 1995), beliefs and values mediate interpretation of work experience and these 
in turn shape the elements regarded as important to in-group membership. They become the desirable attributes to display to one's peers and thus become part of an expression of self to the group. Subscribing to particular aspects of these beliefs and values becomes group defining and thus part of one's social identity (Augoustinos, \& Walker, 1995) where "social identity is that part of the individual's self concept which derives from their knowledge of their membership of a social group (or groups) together with the value and emotional significance of that membership" (p. 98).

Sometimes there is tension between the different communities of practice within interacting activity systems, in part because of the respective social identities of the acting subjects. For example, both controllers and pilots belong to an occupational elite that is driven by the complexity of the work and the stringent selection practices and training requirements of such work. However, there is also competition between the communities because pilots enjoy more status and pay than their groundbased counterparts (Besco, 2000). Occupational jealousy between the two groups has been observed by Besco (2000, p 87) who noted the chagrin of controllers because pilots "get both the money and the girls". This competition has implications for actions for both parties. According to Besco (2000), pilots may resent the controller when a takeoff or landing clearance did not put that particular pilot first. Under these circumstances, as discussed, pilots have been known to bend the "truth" on time estimates to seek a higher priority (Besco, 2000). With developments occurring in the technologies interacting in the activity systems, these attempts are more exposed. Besco (2000) has also observed that air traffic controllers are sometimes intolerant of pilots' mistakes. In turn, some pilots are not forthcoming in revealing a mistake or confusion. This may lead to vague queries or to information not being shared. As the roles of each party change as a result of technological developments (e.g., the movement toward "free flight" where the pilot has greater say in determining their own flight path), these tensions will continue to develop. The quip "are you down there, because I'm up here, or am I up here because you're down there?" is sometimes invoked by pilots to remind controllers of their place. However, historically, these differences were not always so obvious.

One of the central tenets of activity theory is that contradictions present in work activity can be uncovered by examining the historical trajectory of the work undertaken. The history of work practice in Australian aviation reveals that there was more overlap between pilot and controller communities of practice in the past. This overlap was facilitated by requirements and opportunities to physically interact. Indeed, when civil aviation first began in Australia following World War II, civilian air traffic controllers were recruited from the pool of ex-military pilots. For two decades, recruitment of air traffic controllers involved a requirement that such staff had an aviation background, which typically meant that they either held a current pilot's licence or that they were recruited from the military or that their father had been in aviation ${ }^{2}$. When the military labour supply dried up in the 1960s, recruitment practices changed and for the first time controllers were recruited "off the street".

Up until the early 1990s in Australia, many regional airports and out-station towers were staffed by air traffic controllers who commenced their careers in the country, where they gained experience before moving to the faster more congested airspace sectors covering major capital cities. In such country locales, controllers often flew light aircraft themselves and, even if they didn't, they frequently had the opportunity to sort out a difference of opinion with a pilot in the bar of the local aero club where, according to some older interviewees, many an airspace incident was debriefed and resolved.

Historically, it was also in the out-station environment that many pilots also learned their job and developed their expertise. The professionalisation of both jobs now requires streamlined training at tertiary level and little opportunity for shared informal learning in a training environment ${ }^{3}$. Economic imperatives have also resulted in further streamlining of training practices, including the removal of the "nice to know" components of the training programs, such as attachments to airlines (where trainee controllers would fly in the cockpits). Such changes are leading to increased specialisation,

2. Interestingly, the notion that good controllers are born and not made still has some salience for some controllers and brings with it some obvious implications to training. However; this discussion is beyond the scope of this paper.

3. It is interesting to note that in some countries, joint training (of pilots and controllers) is now being conducted. 
together with a decline in opportunities to informally learn about particular aspects of the aviation system and one's role within this system. In the past, this was the role played by a shared community of practice. As a result of changes to a variety of other elements at work within the activity system, access to this shared repertoire of experiences is diminishing. Under these circumstances, changes in technological artefacts, structural changes associated with new rules of recruitment and engagement in work (such as the automatic lodgement of flight plans), the shift in the division of labour to centralising services in two centres and the move to a team-based structure all affect the inventory of shared resources that enable successful accomplishment of joint work within this virtual space. This analysis raises the following questions for consideration when designing an intervention in such work environments:

- What collective memory has been developed over time in the respective communities of practice?

- What role does the collective memory informally held within communities of practice play in learning and in unlearning (necessary to facilitate organisational change)?

- How have changes in the activity system impacted on the historical trajectory of interaction within and between respective communities of practice?

These kinds of questions connect with questions raised through an exploration of the other nodes within the activity system. An analysis of the whole activity system, drawing on the discussion of the nodes, will now provide the means for bringing the analysis together.

\section{Conclusion}

This paper has attempted to make a contribution to third-generation activity theorising. It has illustrated the ways in which joint work at the borders of two interacting activity systems is enabled and constrained by interacting technologies, rules, divisions of labour and social identity. The paper has attempted to enhance understanding of third generation activity theory by drawing on concepts employed in organisational theories around rule use, organising labour to address issues of work complexity such as role differentiation and integration as well as occupational identity and culture. In doing so it has shown how the dimensions of the dimensions of interacting activity systems are implicated in joint work at the borders of those activity systems

When engaging in object-oriented interagency, acting subjects develop practices over time that are shaped by tensions and contradictions historically emerging in the activity system interaction. For example, in analysing how object-oriented interagency is mediated by the tools used in the respective activity systems, it was shown how such joint work practice is made difficult by system development that has created technologies designed to operate within the activity system rather than enhance inter-operability between them. One example of the resolution of such difficulties has been the creation of platforms of system integration through the introduction of tools, such as CPDLC and CDTI, which provide cognitive enhancement for the aircrew by integrating tools into the cockpit that provide information available to the controller. Yet these changes create secondary contradictions mediated by borders of social identity (community), which in turn drive calls for changes in borders of role responsibility (division of labour). Such changes also involve further contradictions in existing work practices by changing the shape of rule-governed behaviour.

Reframing aircrew/controller work practices as joint work at the border of two interacting activity systems also enhances understanding about work in this domain and in particular what enables or constrains successful joint accomplishment of the work practice. Enhancing interdependent working in the aviation industry has long been a concern but, to date, most attention to this issue has focussed on either communicative practices or inter-operability within technological systems. The paper points to a series of borders that represent sources of developmental tension and systemic contradiction in interacting activity systems. 
Analysing the collaborative work of air traffic control and air crew as a representation of joint work at the borders of intersecting activity systems provides a more satisfactory theoretical explanation because it enables a much more multi-layered focus than is present in much of the aviation-human factors literature. Such an analysis affords greater opportunities to the practitioner interested in facilitating design interventions within complex systems undergoing change because it points to how such border-practice problems might be addressed.

Such an analysis draws attention to new questions that are offered to assist those involved in designing interventions in these work environments. These are diagnostic questions that practitioners and scholars interested in improving the prospect of joint practice might ask. The questions seek to provide a vehicle for enhancing joint work at the borders of interacting activity systems, an area that, given the increased interdependencies in work, is likely to be of increasing concern. Through this analysis the paper hopes to contribute to our collective understanding of issues within thirdgeneration activity theory research.

\section{REFERENCES}

Ahonen, H., Engeström, Y., \& Virkkunen. (2000). Knowledge management - the second generation: creating competencies within and between work communities in the competence laboratory. In Y. Malhotra (Ed.) Knowledge Management in Virtual Organizations (pp. 282-305). Harrisburg, PA:IGI Publishing.

Augoustinos, M., \& Walker, I. (1995). Social cognition. London: Sage.

Baker, D.P., \& Salas, E. (1992). Principles for measuring teamwork skills. Human Factors, 34 (4), 469-475.

Besco, R. (2000). Pilot/controller teamwork: an awkward alliance. Business and Commercial Aviation, Sept, $82-88$.

Blackler, F., Crump, N., \& McDonald, S. (1997). Crossing boundaries: some problems of achieving expansive learning in a high technology organization. Paper presented at the EIASM Conference on Organizing in a multi-voiced world. Leuven: Belgium.

Cushing, S. (1995). Pilot-air traffic control communications: it's not (only) what you say; it's how you say it. Flight Safety Foundation. Flight Safety Digest, 1-10.

Dekker, S.W.A. (2000). Controllers or exception managers? To intervene or not to intervene - the central problem in future air traffic control. Flight Deck, 33, 48-51.

Engeström, Y. (1999). Expansive visibilization at work: an activity theoretical perspective. Computer Supported Co-operative Work, 8, 63-93.

Engeström, Y. (2000a). From individual action to collective activity and back: developmental work research as an interventionist methodology. In P. Luff, J. Hindmarch, \& C. Heath (Eds.), Workplace studies: Recovering work practice and informing system design (pp. 150-166). Cambridge: Cambridge University Press.

Engeström, Y. (2000b). Activity theory as a framework for analyzing and redesigning work. Ergonomics 43(7): 960-974

Engeström, Y. (2001) Expansive learning at work: toward an activty theoretical reconceptualization. Journal of Education and Work, 14(1), 133-156.

Engeström, Y. (2004). New forms of learning in co-configuration work. Journal of Workplace Learning, 16, $11-21$

Engeström, Y. (2005). Developmental work research: expanding activity theory into practice. Berlin: Lehmanns Media.

Engeström, Y. (2006) From well-bounded ethnographies to intervening in Mycorrhizae activities. Organization Studies, 27, 1783- 1793. 
Engeström, Y., Engeström, R., \& Karkkainen, M. (1995). Polycontextuality and boundary crossing in expert cognition: learning and problem solving in complex work activities. Learning and Instruction, 5, 319336.

Engeström, Y., Engeström, R, \& Kerosuo, H. (2003). The discursive construction of collaborative care. Applied Linguistics, 24, 286-315.

Engeström, Y., Engeström, R., \& Vähääho, T. (1999). When the center does not hold: The importance of knotworking. In S. Chaiklin, M. Hedegaard, \& U.J. Jensen (Eds.), Activity theory and social practice (pp. 345-374). Aarhus: Aarhus University Press

Field, E., \& Harris, D. (1998). A comparative survey of the utility of cross-cockpit linkages and autoflight systems' backfeed to the control inceptors of commercial aircraft. Ergonomics, 41(10), 1462-1477.

Fine, G.A. (1996). Justifying work: occupational rhetorics as resources in restaurant kitchens. Administrative Science Quarterly, 41, 90-115.

Flach, J. (1999). Beyond error: The language of coordination and stability. In E. Carterrette, \& M. Friedman (Eds.), Handbook of perception and cognition: human performance and ergonomics (2nd edition) (pp. 109-130). San Diego: Academic Press.

Fowler, R. (1999). Improving communications with ATC. Plane and Pilot, 35(1), 70-72.

Gerber, R., \& Lanksherar, C. (Eds.) (2000). Training for a smart workforce. London, New York: Routledge.

Hartel, C., \& Hartel, G. (1995). Controller resource management: what can we learn from aircrews? Washington: Federal Aviation Administration.

Hollnagel, E., Woods, D.D., \& Leveson, N. (Eds.) (2006). Resilience Engineering. Concepts and Precepts. Aldershot, UK: Ashgate.

Howitt, A.M., \& Leonard, H.B. (2006). Katrina and the core challenges of disaster response. The Fletcher Forum of World Affairs, 30(1), 215-221.

Jentsch, F., Barnett, J., Bowers, C.A., \& Salas, E. (1999). Who is flying this plane anyway? What mishaps tell us about crew member role assignment and air crew situation awareness. Human Factors, 4(1), 1-14.

Jones, G. (1995). Organizational theory: text and cases. Reading, Mass: Addison-Wesley.

Kanki, B.G., \& Palmer, M.T. (1993). Communication and crew resource management. In E.L Wiener, B.G. Kanki, \& R.L. Helmrich (Eds.), Cockpit resource management (pp. 99-136). San Diego, London: Academic Press.

Kerns, K. (1999). Human factors in air traffic control/flight deck integration: implications of data-link simulation research. In D.J. Garland, A.J. Wise, \& V.D. Hopkin (Eds.), Handbook of aviation human factors (pp. 519-546). London: Lawrence Erlbaum \& Associates.

Loftus, G.R. (1979). Short-term memory factors in ground controller/pilot communication. Human Factors, 21(2), 169-181.

McCann, C., Baranski, J., Thompson, M., \& Pigeau, R. (2000). On the utility of experiential cross-training for team decision-making under time stress, Ergonomics, 43(8), 1095-1110.

McCarthy, J., Healey, P., Wright, P., \& Harrison, M.D. (1997). Accountability of work activity in highconsequence work systems: human error in context, International Journal Human-Computer Studies, 47, 735-766.

McGann, A., Morrow, D., Rodvold, M., \& Mackintosh, M-A. (1998). Mixed-media communication on the flight deck: a comparison of voice, data link, and mixed ATC environments. The International Journal of Aviation Psychology, 8(2), 137-156.

Morrow, D., Rodvold, M., \& Lee, A. (1994). Nonroutine transactions in controller-pilot communication. Discourse Processes, 17, 235-258.

Nardi, B. (1996). Context and consciousness: activity theory and human computer interaction. London: MIT Press. 
Orlady, H.W., \& Orlady, L.M. (1999). Human factors in multi-crew flight operations. Aldershot, Brookfield USA, Singapore, Sydney: Ashgate.

Owen, C. (1999). Learning in the workplace: The case of air traffic control. Unpublished PhD dissertation, University of Tasmania.

Owen, C. 2001 The role of organisational context in mediating workplace learning and performance. Computers in Human Behaviour, 17 (5/6), 597-614;

Prinzo, O.V. (2004). Automatic dependent surveillance-broadcast/cockpit display of traffic information: innovations in pilot-managed departures. The International Journal of Aviation Psychology, 14(2), 171.

Rantanen, E.M., McCarley, J.S., \& Xu, X. (2004). Time delays in air traffic control communication loop: effect on controller performance and workload. The International Journal of Aviation Psychology, 14(4), 369.

Rouilleault, H. (2000). Work organization and information and communication technologies. In K. Rubenson, \& H.G. Schuetze (Eds.), Transition to the knowledge society: policies and strategies for individual participation and learning (pp. 209-218). Canada: UBC Institute for European Studies.

Salas, E., Bowers, C.A., \& Edens, E. (2001). An overview of resource management in organizations: why now? In E. Salas, C.A. Bowers, \& E. Edens (eds), Improving teamwork in organizations: applications of resource management training (pp. 1-5). Mahwah, London: Lawrence Erlbaum.

Salas, E., Stagl, K., \& Burke, S. (2004). 25 years of team effectiveness in organizations: Research themes and emerging needs. In C. Cooper, \& I.T. Robertson, International Review of Industrial and Organizational Psychology, 19, 47-9.

Segal, L.D. (1994). Actions speak louder than words: how pilots use nonverbal information for crew communications. Proceedings of the Human Factors and Ergonomics Society $38^{\text {th }}$ Annual Meeting, 21-25.

Smith-Jentsch, K., Baker, D., Salas, E., \& Cannon-Bowers, J. (2001). Uncovering the differences in team competency requirements: the case of air traffic control teams. In. E. Salas, C.A. Bowers, \& E. Edens (Eds). Improving teamwork in organizations: applications of resource management training (pp. 294320). Mahwah, London: Lawrence Erlbaum.

Suchman, L. (1993). Technologies of accountability: of lizards and aeroplanes. In G. Button (Ed.). Technology in working order: studies of work, interaction, and technology (pp. 113-126). London, New York: Routledge.

Suchman, L. (2000). Located accountabilities in technology production, Lancaster University: Department of Sociology, 13. http://www.comp.lancs.ac.uk/sociology/soc039ls.html

Victor, B., \& Boynton, A.C. (1998). Invented here: Maximizing your organization's internal growth and profitability. Boston: Harvard Business School.

Virkkunen, J. (2006). Dilemmas in building shared transformative agency. @ ctivites, 3(1) 43-66

Weick, K. E. (2006). Shouldering risks: the culture of control in the nuclear power industry. The Academy of Management Review, 31(3), 766.

Wiener, E.L., Kanki, B.G., \& Helmrich, R.L. (Eds.) (1993). Cockpit resource management. San Diego, London: Academic Press, 99-136.

Woods, D. 2006. Essential characteristics of resilience. In E. Hollnagel, D. Woods, \& N. Leveson (Eds.), Resilience engineering. Concepts and precepts (pp. 21-34). Aldershot: Ashgate.

Yule, S., Flin, R., \& Murdy, A. (2007). The role of management and safety climate in preventing risk-taking at work. International Journal of Risk Assessment and Management, 7(2), 137-151.

RÉSUMÉ

Analyser le travail conjoint entre différents systèmes d'activité.

L'objectif de cet article est de contribuer au développement d'une troisième génération de travaux centrés sur la théorie historico-culturelle de l'activité. L'analyse porte sur des sujets (inter)agissants, lorsqu'ils sont impliqués dans 
un travail conjoint situé aux frontières de leurs systèmes d'activité respectifs. L'article discute, de manière théorique, les problématiques soulevées par ces situations, en analysant les pratiques observées lors d'interactions entre des pilotes et des contrôleurs aériens. Les analyses portent sur la manière dont les pratiques de travail sont médiées conjointement, lorsque des changements surviennent dans des systèmes d'activité en interaction. Elles permettent de montrer de quelle manière un changement apporté aux éléments d'un système d'activité génèrent des tensions et des contradictions, et ce faisant, des opportunités de développement dans les interactions quotidiennes entre les contrôleurs aérien et les pilotes de ligne. Sur cette base, l'article définit des problématiques clés à étudier lorsqu'il s'agit de concevoir des interventions dans ces environnements de travail, et contribue au développement d'une troisième génération de recherche sur la théorie historico-culturelle de l'activité.

\section{MotS CLÉS}

Théorie historico-culturelle de l'activité; coordination entre contrôleurs aérien et pilotes d'avion, collaboration, théorie des organisations.

\section{RESUMEN}

Analizando el trabajo conjunto entre sistemas de actividades. El objetivo de este artículo es realizar un aporte al desarrollo de una tercera generación de teorías de la actividad. Lo hace a través del análisis de sujetos que (inter)actúan comprometidos en un trabajo conjunto realizado en los límites de sus respectivos sistemas de actividades. El artículo explora estos problemas desde una perspectiva teórica y discute las prácticas observadas en una interacción entre pilotos y controladores aéreos en la industria aeronáutica. En este caso, se analiza la manera en que las actividades laborales están conjuntamente mediatizadas a través de cambios que ocurren en sistemas de actividades interactivas. El análisis mostrará cómo los cambios en los elementos de los sistemas de actividades revelan puntos de tensión y de contestación y, por ende, oportunidades para el desarrollo de las interacciones cotidianas entre los controladores aéreos y los pilotos de línea. Al abordar el análisis, el artículo introduce algunas preguntas clave a considerar cuando se diseñan las intervenciones en este tipo de entorno laboral, y contribuye al desarrollo de una teoría de la actividad de tercera generación.

Palabras Clave

Teoría histórico-cultural de la actividad, coordinación tripulación/control aéreo, colaboración, teoría organizacional

\section{REFERENCING}

C. Owen (2008). Analysing joint work between activity systems. Activités, 5 (2) pp. 52-69, http://www. activites.org/v5n2/v5n2.pdf

Date received : july 2006, Date accepted : september 3, 2008. 